\section{Bicultural Education in Aotearoa/New Zealand: Establishing a Tauiwi Side to the Partnership}

\section{KEITH SULLIVAN}

\section{Abstract:}

In this paper, the author discusses the development of ideologies about multiethnic ${ }^{1}$ educational policy in Aotearoa/New Zealand in terms of four successive stages: assimilation, integration, multiculturalism and biculturalism. He argues that we need to develop a form of biculturalism that fully acknowledges Maori as tangata whenua and which is centred upon a Maori/Tauiwi partnership rather than the present Maori/Pakeha primary relationship. He also suggests we need to articulate clearly what we mean by biculturalism and to understand both the ideologies and philosophies that have been developed during the four stages in order to develop useful policy and practice. The author adopts James Banks' concept of the multiethnic paradigm as an analytical tool to assist this process.

1 993 was the United Nations Year of Indigenous People. In our emerging post-colonial world, this is a timely and appropriate acknowledgment of the global condition of indigenous peoples. Throughout the world the process of colonisation has stripped them of their lands, disenfranchised them, and thrown them into an underclass position, in social, economic and educational terms. Now, they are reclaiming their languages, their heritages, their mana. Culturally appropriate education is crucial to this process of re-empowerment. In Aotearoa/New Zealand, while there has been widespread awareness for almost three
192 Keith Sullivan

decades of inequities in the educational system, the introduction of apparently progressive programmes such as Taha Maori was suggested and controlled by well-meaning Pakeha, often without consultation or support from the Maori communities (see Graham Smith, 1990, for a critical discussion of Taha Maori). Ideologically, and indeed practically, this is nolonger acceptable or appropriate.

Over the last 20 years, a strong and clearly articulated Maori voice has been making creative inroads into Aotearoa/New Zealand's monocultural education system. The successes of Kohanga Reo and Kura Kaupapa Maori schools have made Maori educators world leaders in the development of effective education for and by indigenous peoples. ${ }^{2}$ Imperative to this educational development is a schooling system that both values and supports te reo and nga tikanga Maori (Maori language and culture), and which in a fundamental way also acts as a vehicle for the participation in and ownership of education not only by Maori children but also by their iwi, hapu and whanau, their tribes, subtribes and families. These developments have occurred mainly as a result of Maori assertiveness and rational separate development.

In historical terms, a putative partnership was established with the signing of the Treaty of Waitangi between the Maori inhabitants of Aotearoa/New Zealand and the British Crown in 1840. The Treaty guaranteed the rights of sovereignty, tino rangatiratanga, and full British citizenship to Maori in exchange for allowing British governorship, kawanatanga. Interpretations of these rights have been in dispute ever since, ${ }^{3}$ and from the time of the signing until recently, Maori sovereignty has not been supported in any tangible way. Pakeha responsibility to honour the Treaty was largely ignored. As a result, "The Treaty is a fraud" was a slogan that frequently and graphically expressed the sentiments of many Maori, especially the urban young. Recently, however, through a wave of Maori activism and re-thinking, the Treaty has been reformulated as a partnership. Standing on this firm base, many Maori are demanding that tino rangatiratanga as 
originally agreed to in the Treaty must now be put in place and past injustices redressed. This will involve, among other things, a thorough reappraisal of the education system, which must come about through the creation of appropriate policy and its implementation in existing or new institutions and forms. A way of thinking which will encourage this implementation is the focus of this paper.

\section{Establishing a Definition of Biculturalism}

In order to analyse how the formal education system has served Maori and in order to examine ways of facilitating the partnership, I will trace the development of thinking about multiethnic education in Aotearoa/New Zealand. There is a need to do this not only for reasons of social responsibility and justice, but also for the cultural health and the future well-being of nonMaori as well as Maori.

Peters and Marshall (1989) identify five distinct phases in the European educational policy for Maori: assimilation, integration, cultural difference, multiculturalism and biculturalism.

The history of policy can be seen in a number of clearly discernible successive phases: an "assimilationist" approach to race relations which predominated up until the late 1950s; a focus on a policy of integration implicitly based on a notion of cultural deprivation during the 1960s and early 1970s. This was followed by a transitional period where emphasis was shifted from "cultural deprivation" and "the problem of the Maori child" to a concept of "cultural difference" which emphasised Pakeha tolerance of non-Pakeha culture; and, finally, an attempt to formulate a multicultural policy with the attendant notion that "cultural diversity" should be valued. Most recently, there have been some signs that we are moving into a policy era of "biculturalism", primarily as a result of Maori initiatives (p. 142).

Irwin (1989) similarly suggests five stages, although she categorises them differently. As Peters and Marshall do, she identifies the first phase from early settlement until 1960 as assimilation. She rightly identifies the Hunn Report (1960) as the initiator of the next or integration stage. Her third stage, however, she terms cultural pluralism rather than Peters and Marshall's cultural difference. Irwin then identifies her fourth stage as biculturalism, in which the central concern is the need to sort out the Maori/Pakeha partnership and to continue the surge of Maori educational development through this bilateral partnership so that multiculturalism, the fifth stage, can be reached.

Contrary to Peters and Marshall, and Irwin, I argue for four successive stages in Maori educational policy and practice: assimilation, integration, multiculturalism and biculturalism. While Peters and Marshall's summation is useful, I would argue that acknowledgment of cultural difference (depending on the degree of tolerance) is a characteristic of multiculturalism rather than a policy stage in its own right. Therefore I would incorporate "cultural difference" into the multiculturalism phase, and recast Irwin's cultural pluralist phase as multiculturalism. ${ }^{4}$

Since these 1989 analyses, we have clearly moved into a Maori-initiated and driven bicultural stage which makes it possible for us to reframe our thinking on Maori educational policy and practice. ${ }^{5}$ While it may be useful to identify biculturalism as a stage on the way to multiculturalism in that it indicates an evolving response to a complex and difficult question, this approach is also fraught with difficulties. It may be seen as denigrating the status and claims of the indigenous people, and may be used to justify the power held by the dominant group. While the concept of multiculturalism may be a convenient umbrella, it should not be used as a way of obscuring the torrent of demands for recognition and redress put forward by the tangata whenua.

In relation to educational policies that respond to the oppression of Blacks in Britain, Brandt (1986) identifies four phases: assimilation, integration, cultural pluralism and antiracism. The context for Brandt is, of course, different from that in 
Aotearoa/New Zealand. Brandt speaks on behalf of the Black British immigrant community rather than an indigenous group, but it could be argued that what Brandt's anti-racist phase shares with biculturalism and what distinguishes them both from the other phases is that the impetus and input comes from the oppressed group, i.e., from the Black and the Maori communities respectively, rather than from the dominant group. Similarly, while Banks (1988) argues for the development of multiculturalism as an appropriate response in the United States of the 1990s, the particular context of Aotearoa/New Zealand demands primarily a bicultural framework, which is informed by many of the same issues as multiculturalism.

I would therefore argue for a form of biculturalism as a full stage in its own right, rather than as a transitional stage to multiculturalism, a biculturalism that upholds the Treaty of Waitangi and permanently acknowledges Maori as tangata whenua and all that this entails. I would also argue that a rethinking of the nature of the bicultural partnership should provide the philosophical and cultural impetus for effective policy-making, redressing the ethnic inequalities of Aotearoa/New Zealand and building a pro-active path to the future. Let me elaborate further on this.

I posit that biculturalism has at its core four central principles:

1. Biculturalism is an equal partnership between two groups that values and supports cultural diversity.

2. Maori are acknowledged as the tangata whenua, the original inhabitants of Aotearoa/New Zealand.

3. The Maori translation of the Treaty of Waitangi is acknowledged as the founding document of Aotearoa/New Zealand. ${ }^{6}$

4. Biculturalism is concerned with redressing past injustices and re-empowering the indigenous people. Implicit in this principle is the acknowledged fact that after a century and a half of cultural domination, Maori set their own path and make their own decisions about Maori development in partnership with non-Maori.

Within a framework that accepts the validity of these principles, I have encountered two main definitions of biculturalism, both of which are problematic. As an alternative, I have developed a third definition which combines the important features of the first two but recontextualises them so that they accurately reflect Aotearoa/ New Zealand in 1993 and in so doing counter the difficulties inherent in the first two. The three definitions are as follows:

\section{Biculturalism One: the Great Multicultural/Bicultural Debate}

Central to this understanding of biculturalism is the notion that before we can consider issues of multiculturalism, i.e., issues that relate to other minority groups, we need to address and rectify the inequalities within the primary cultural relationship of Aotearoa/New Zealand between Maori and Pakeha, and that we must also revisit this partnership so that the original intentions are reflected in both a redeveloped ideological framework and also in practical ways such as more equitable educational outcomes. In this context, multicultural concerns and policies are seen as a way of dissipating the strength of focus that biculturalism brings.

A common multiculturalist counter-argument is that biculturalism excludes non-Maori/Pakeha individuals and groups from effectively exercising their rights as New Zealand citizens. Vasil (1988) rebuffs such arguments by suggesting that reactionary elements in our society use multiculturalism as a blind, a way of avoiding addressing the difficult challenges that biculturalism brings with it. He states:

Some Pakeha, who in the past had rarely thought of New Zealand as anything other than a white Western nation, now faced with Maori demands for its recognition as a bi-racial and bicultural nation, insist on arguing with a certain vehemence 
that New Zealand, in view of the existence of many ethnic minorities, can properly be viewed only as a multi-cultural and multi-racial society. They insist that in fairness the identity and cultures of the other ethnic components - the Chinese, the Indians, the Greeks, the Dutch, etc. - cannot be ignored. They argue that if the separate culture, language and identity of the Maori were to be given a special recognition, the same privilege could not be denied the others. This newfound concern for the interests of the non-Maori ethnic minorities in New Zealand by the Pakeha must be looked at closely. (p. 1)

The dissection and analysis of issues of biculturalism and multiculturalism for various means and ends has had an interesting history. Rocher (1984), in discussing the French/ English conflict in Canada during the 1970s, describes and defends a position that is based on bilingualism and biculturalism as opposed to the Landreau Commission's support for bilingualism in a multicultural framework. Rocher's argument is based on a fear that if all ethnic groups are given an equal voice, then the uniqueness of French-Canadian/Quebecois culture would be lost amongst a myriad of other cultures; it would also mean that the already dominant English Canadian culture would become even more powerful at the expense of Quebecois. He argues then for a biculturalism where Canada's two founding groups are acknowledged as such and where new groups retain their ethnicity but ally themselves with one of these two main groups.

I would argue that the flaw in this argument is that it ignores Canada's indigenous people. From a Maori perspective there would be merit in the "two founding groups" argument but not in the identification of those two groups.

\section{Biculturalism Two: Multiple Biculturalism}

A second definition that has emerged addresses the exclusion problem of the first definition and as a solution envisages biculturalism as a series of multiple bilateral interfaces, for instance, a Maori/Pakeha interface, a Maori/Samoan interface, a Samoan/Pakeha interface. This is seen as a way of simplifying multicultural issues by focusing on the cultural interaction of any two Aotearoa/New Zealand ethnic groups at any one time, i.e., a series of bicultural relationships is central to this perspective.

This definition is problematic because it can be argued that it gives the appearance of biculturalism while in fact being a form of multiculturalism, and that it is an attempt to appease those who feel excluded by the first definition, and by so doing it undermines the key issue of biculturalism, the Maori/Pakeha partnership.

\section{Biculturalism Three: a Maori/Tauiwi Partnership}

In relation to the first definition, members of non-Maori minority groups, such as Samoan or Cook Island New Zealanders, may ask: "If the Pakeha/Maori relationship is the primary relationship, where do we fit in?"

On the other hand, in relation to the second definition, Maori may feel that their position based on tangata whenua status and Treaty rights is watered down when placed in a plethora of equal "bicultural relationships". Both of these definitions also contribute to the creation of an unnecessary tension between Maori and other ethnic minority groups. The appearance is given that Maori, by demanding an exclusive bicultural policy, are making unfair demands that, when met, exclude other deserving groups such as the Samoans, Tongans and Niueans of the Pacific Island community from their rightful access to limited educational resources, for instance.

I posit a third definition that upholds the central principles of biculturalism but changes the nature and composition of the 
partnership and releases Maori from any falsely attributed responsibility for the exclusion of other minority groups. It goes as follows:

Aotearoa/New Zealand is no longer a large colonial sheep and dairy farm in the South Pacific providing cheap produce to Mother England. We are an emerging multiethnic Pacific nation in the process of re-defining, in our own terms, who we are and what our relationships with the wider world are.

We are a nation founded on the Treaty of Waitangi, a bilateral agreement between the tangata whenua, the various tribes that made up the Maori population of that time, and the British Crown. The number of British settlers in 1840 was small. Under the Treaty, Maori agreed to British governance, kawanatanga, of their country, while retaining tino rangatiratanga, sovereignty. Since the signing of the Treaty, its spirit and the terms have been blatantly and consistently ignored by the Pakeha. Over the years as the Pakeha population has grown, Maori have been disenfranchised, their language and culture undermined and their lands taken over. These injustices are now starting to be redressed.

From a demographic perspective, Aotearoa/New Zealand in 1993 is very different from the sparsely and almost exclusively Maori populated country of 1840 . Although a largely British descendent group now make up the majority population, there are many others who have arrived from other parts of the Pacific and the wider world. The power of the British Crown in Aotearoa/New Zealand is now nominal rather than real, so if there is to be a modern partnership, this should be between the tangata whenua (the combined Maori tribes who are the descendants of the Maori who originally signed the Treaty) and the descendants of those Pakeha who settled from England and Europe as well as all other groups and individuals who have arrived since. In other words, in order accurately to represent our contemporary ethnic makeup and political system, the concept of a Maori/Pakeha partnership in a bicultural context should be replaced by a Maori/Tauiwi relationship.
Tauiwi includes all non-Maori Aotearoa/New Zealanders, be they of English, Dutch, Samoan, Cook Island, Tongan, Niuean, Chinese, Indian or other descent. This interpretation of biculturalism acknowledges the rights of the tangata whenua and also includes all non-Pakeha New Zealanders in this important partnership.

\section{The Ideological Development of Multiethnic Education in Aotearoa/New Zealand}

Having established the significance of biculturalism, it is important to understand the wider context, the characteristics of this stage, their provenance and why they have evolved as they have.

In order to do this I have developed a framework for understanding the ideologies and the resultant policy and practice of the four educational policy stages which incorporates Banks' (1988) ten paradigms as an analytical tool. These paradigms were developed as a response to American and British multiethnic issues, but I would argue that they are also useful in the context of Aotearoa/New Zealand.

I have arranged these paradigms sequentially in a continuum that goes from political right to left, from reactionary right wing to radical left-wing and which, because the development of educational policy and practice has generally coincided with a liberalisation of attitudes along this continuum over the last 30 or so years fits in well with the four stages. Diagramatically, the relationship between the four stages and the paradigms is as below.

In my analysis, the first three of Banks' paradigms fall under the heading of assimilation and the fourth and fifth under the heading of integration. Of the remaining five paradigms, cultural difference is clearly an initial form of multiculturalism, but the other four could be intrinsic to both multiculturalism and biculturalism and therefore cannot be easily assigned to only one or the other of these. 
The 4 Stages

\section{Banks' 10 Paradigms}

1. The genetic paradigm

2. The assimilation paradigm

3. The cultural deprivation paradigm

Integration

4. The ethnic addictive paradigm

5. The self-concept development paradigm

III

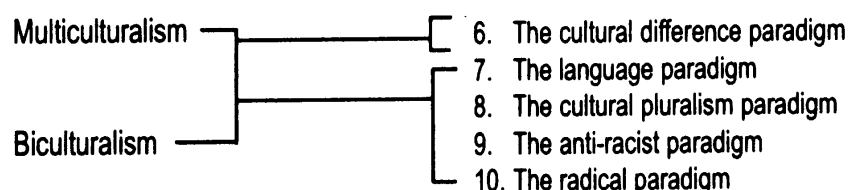

IV

10. The radical paradigm

Figure 1 The Historical and Ideological Development of Multiethnic Education in Aotearoa/New Zealand ${ }^{7}$

These paradigms are particularly useful as an analytical tool in this instance because:

1. Paradigms are developed as a way of conceptualising and explaining a particular phenomenon at a particular time, and as our understanding develops or circumstances change, these paradigms are superseded by newer and more appropriate models.

2. They are particularly useful because they are logical and easy to understand, that is, if a particular ideological or philosophical perspective is identified, then there is usually a clearly discernible path from this to the development of related educational policies and on to their practice in the classroom. An understanding of this process can help to reveal or unmask the intentions of the policies of pressure groups or government.
For example, Hekia Parata (1993) discusses the last National Government's Maori policy of mainstreaming which she argues is only tenuously linked to any Maori impetus and which in fact she reveals as assimilationist. It can also be argued that it illustrates the cultural deprivation syndrome. While the Government made much of Winston Peters' "Ka Awatea" document, and used it to justify the implementation of mainstreaming, Parata says that "[mainstreaming] was mentioned not at all in any of the report's 68 final recommendations. It is difficult to determine exactly how mainstreaming became the Government's Maori affairs policy" (p. 19).

While the policy is claimed to be progressive, since it is nominally linked with the much lauded educational policy of mainstreaming or inclusive education for disabled children, Parata suggests that it is in fact reactionary:

Mainstreaming assumes that Maori are the same as the rest of the population, and that if they are treated the same they will behave the same way. This assumption persists, despite empirical and anecdotal evidence to the contrary collected over many years (p. 19).... Main-streaming is most certainly not a Maori affairs policy. At best it is a rationalising of housekeeping functions and monies in the state sector. At worst it is a rationalising of unsuccessful assimilationist policies (p. 20)

If put to the test, therefore, mainstreaming would be in direct conflict with the ideologies, policy and practice associated with the Maori side of our bicultural partnership. By using Banks' paradigms, it is possible to identify the provenance of mainstreaming and to reveal it as a contemporary reiteration of the assimilation paradigm.

3. When used with the four-stage theory, Banks' paradigms provide us with insights at the macro and micro levels. In other words, the four-stage theory provides an overview of 
what is happening during a particular time period. The paradigms complement this by dealing with a more specific understanding of the ideologies and their consequences, i.e., the former is generalised and impressionistic, the latter is more analytical and particular.

It should be pointed out, however, that single-factor paradigms such as these are oversimplified, and that there is not a strict one-to-one adherence between the stages and the paradigms. There is often an overlap between policy and practice, but they are presented in this analysis in a singlefactor fashion so as to facilitate understanding. In order to develop a complex response to a complex situation, several paradigms can be and have been wholly or partially used to develop a multi-factor paradigm, as is suggested by Banks. Although models are very useful in helping us understand how things work, in the real world things are never as straightforward and simple as they are portrayed in models. While Banks' last five paradigms may apply equally to multiculturalism and to biculturalism, the status of the tangata whenua must always be upheld through the primacy of biculturalism, and thus an inclusive multi-factor paradigm may be posited here.

\section{The Four Stages and Their Accompanying Paradigms}

\section{The assimilationist stage}

Godfrey Brandt (1986) describes assimilation in the British context as follows:

State policies in general, and education policies in particular, in the sixties were based on a liberal notion of assimilation.

This assimilation was predicated by a liberal racism which implied that though Black people were not as yet equal to white people, if they assimilate and get lost in the fabric of the tapestry of British life they will not be problems and may even become equal (p. 13).
Assimilation in the New Zealand state school system was characterised by the attempt to Europeanise Maori through excluding Maori culture from the curriculum and by banning the use of Maori language in schools. From 1907, more Maori children attended Board schools than the separately run and largely rural Maori schools and were therefore consistently subjected to these assimilationist policies. Despite Maori academic successes, most notably at Te Aute College, a private Maori boarding school, a policy of adapted education was introduced in 1930 and applied specifically in Maori schools. Basic skills and aspects of Maori culture were taught (although not Maori language), and Maori students were encouraged to stay in their home areas. Barrington (1976) states that:

The new policies placed particularly strong emphasis on agricultural and gardening activities. In the view of the Director of Education, T. B. Strong, the best means for the Maoris to realize the full benefits of civilisation was for them to cultivate their land. Thus, "we should provide fully a type of education that would lead the boy to become a good farmer and the girl to become a good farmer's wife. Teachers in Maori schools were enjoined to "study the social life, music, recreation and arts and craft of the Maori people" and to occupy the greatest amount of time in history lessons with stories of Maori and New Zealand history (p. 3).

The underlying philosophy of this form of education was that the overwhelming majority of Maori were suited only for a particular type of work, largely physical and unskilled, theimplication being that this was appropriate for their limited abilities and lesser intelligence.

Although there was an attempt to include Maori material in these schools, the new policies introduced in 1930 remained assimilationist in essence and also illustrate the genetic paradigm which is a facet of assimilationist philosophies. The policies also indicate the attitudes of superiority and patronage exhibited by the Pakeha policy-makers. 
I have placed three of Banks' paradigms under the umbrella of assimilation: the genetic, assimilation and cultural deprivation paradigms.

1. The genetic paradigm. This paradigm is an extreme example of the underlying thinking of assimilationism. Supporters of this paradigm attribute educational failure of minority groups to their genetic makeup. In 1969, Arthur Jensen, professor of psychology at the University of California at Berkeley, suggested that the reason compensatory programmes such as Head Start and Follow Through (which had been designed to increase the IQ of Afro-Americans living in the urban ghettoes) had failed was that the people whom they were designed to help were genetically inferior (rather than because of the multitude of factors that acted together to disadvantage Afro-Americans in this setting). ${ }^{8}$

The genetic paradigm is a racist paradigm. Because supporters of this paradigm believe that the reason some groups do not perform well in school is solely genetic, they have no commitment to educational equality for ethnic minority students and use this argument to avoid implementing educational programmes which aim to address equity issues. They believe that there is, for instance, no real need for ethnic minority programmes, such as Kura Kaupapa Maori, because if a genetic difference exists between Maori and Pakeha this cannot be alleviated by such educational programmes.

A logical policy of this paradigm is that within a state school system students are assigned to streamed classes according to their intelligence as demonstrated in IQ and other tests of mastery. As a result of such policies, a highly disproportionate number of ethnic minority children end up in low academic streams. This puts into effect the self-fulfilling prophecy syndrome.

If, in this setting, the self-fulfilling prophecy is accepted as the probable reality, then one can conclude that streaming tends to perpetuate inequality. It supports the dominant hegemonic structure of society, maintains class and ethnic stratification, and teaches low-stream students to accept their diminished status.

2. The assimilationist paradigm. This model is another conservative stance that in fact pre-dates Jensen's articulation of the genetic argument. This approach to education dominated government policy in various forms in Aotearoa/ New Zealand from the onset of colonisation up until the 1960s and was so influential that the first stage also carries this name.

The underlying philosophy of the assimilationist paradigm is not as blatantly racist as the genetic paradigm. Its basic tenet is that minority group children will benefit most from their education if they are absorbed into the dominant culture. This is, of course, a patronising approach that assumes cultural superiority. In Aotearoa/New Zealand, Maori children were expected to give up their ethnicity, their culture and their language and to take on the characteristics of the dominant culture. In order to get ahead in the dominant Pakeha world, they would be expected to learn the ways of the white patriarchy in order to succeed.

An underlying theme of the assimilationist policy is that encouraging ethnicity would undermine national unity and encourage the development of little enclaves or ghettoes of people who could be at odds with the national interest. Cultural and linguistic difference in this setting is not valued but is seen as a threat.

The main goal of assimilationist education is to teach minorities the values and behaviour of the majority culture, and part of the process is the surrender by minority groups of their ethnicity, culture and language in return for access to all the goods of the dominant society. Educationally, assimilation is achieved largely through the specific aims and shape of the 
curriculum, which is geared to the culture and style of the dominant group. The reality for those coerced into denying their cultural and linguistic heritage is that this sacrifice does provide access to the promised areas. The result is alienated and unhappy individuals caught between cultures. Bourdieu (cited in Harker, 1990) charges that the acculturated individual does not reap the promises of assimilation, i.e., success within the mainstream culture. Instead, although he or she may acquire some dominant group cultural capital, the school system sees that the individual does not generally rise above the second of five levels in which inequalities are perpetuated. ${ }^{10}$

3. The cultural deprivation paradigm (often referred to as the deficiency syndrome). As we move away from the conservative end of the scale, the next paradigm we encounter is the cultural deprivation paradigm. The main assumption of this paradigm is that the family and culture of ethnic minority children do not provide either adequate stimulation or preparation for education, as does the middleclass Pakeha home in the Aotearoa/New Zealand instance. Therefore, the child arrives at school ill-prepared and disadvantaged and continues to be disadvantaged as he or she passes through the various stages of the education system. These children are seen then as starting their education from a position of deficit. Their own culture and language are seen as deficient and inferior and as holding them back.

The aim of education policy for this paradigm is to address these perceived deficits, and so school programmes are developed to provide children with a programme to help them to catch up. Head Start in the United States was such a compensatory programme intended to be behaviouristic and intense. There is an implied assumption in this paradigm that the minority culture is dysfunctional, and that not only does it prevent children from acquiring the correct socialisation (cultural capital), but also retards their cognitive development.
The intentions of the cultural deprivation model are arguably not as negative as the genetic paradigm in that they do not dismiss the ethnic minority child as being genetically fixed and therefore unchangeable. This model does, however, dismiss the child's culture and background as inferior. In Aotearoa/New Zealand terms, then, this would translate that Maori children perform poorly in school because their culture and whanau are deficient. The suggested path would be to provide Maori children with various compensatory programmes in order to give them better access to the skills provided in the family setting of middle-class Pakeha society. The intentions of the programme are obviously culturally imperialistic but are cloaked in well-intended equitybased policies aimed at giving the child a fair chance. Policies and practice from this paradigm, in particular, held sway for a very long time and did experience a revival in the 1980s.

\section{The integration stage}

The integration stage can be characterised as the start of the acknowledgment of cultural diversity. Educationally there is some appreciation of things different, but only through the eyes of the dominant society. Ethnic minorities are idealised as the "noble savage", i.e., they are regarded as exhibiting the simple and honest values that are lost in the dominant society. They represent a simpler lifestyle, the dominant society in its more primitive form. So, in other words, indigenous and other groups are valued for what they appear to represent for the dominant society rather than what they are in their own right. It is a superficial appreciation of cultural diversity. Thus Street-Porter (1978) describes integration as "... a modest tokenism, an acceptance of that which is quaint in minority culture but a worried rejection of those cultural aspects that seem not just alien but feel threateningly so" (pp. 50-51).

As Irwin (1989) suggests, the Hunn report heralded the introduction of integration into Aotearoa/New Zealand education. She describes integration as follows: 
a less crude, less racist version of assimilation. Whereas the racist, ethnocentric judgements about cultural superiority were an overt part of the ideology of assimilation, they became covert aspects of integration. Contrary to the view that policy-makers would have us believe, such notions are not removed from new policy areas, they are simply disguised. Integration is described as a more liberal and humane version of facilitating the interaction of two cultures. Lack of equal opportunity is recognised and a new promise of equality of opportunity made (p. 4).

The Hunn Report acknowledges integration as "New Zealand's policy for the future" and defines it as "To combine (not fuse) the Maori and Pakeha elements to form one nation wherein culture remains distinct" (p. 15). The report is a clear example of attitudes that typify the integrationist stage:

Integration, as stated, implies some continuation of Maori culture. Much of it, though, has already departed and only the fittest elements (worthiest of preservation) have survived the onset of civilisation. Language, arts and crafts, and the institutions of the marae are the chief relics.... Every Maori who can no longer speak the language, perform the haka or poi, or take his place on the marae, makes it just so much harder for these remnants of Maori culture to be perpetuated (p. 15).

Within this integrationist stage, two of Banks' paradigms fit: the ethnic additive and the self-development paradigms.

4. The ethnic additive paradigm. This model is marginally better than the assimilationist paradigms. It attempts to meet the needs of the child rather than leaving her to sink or swim in the curriculum of the dominant group. This may be done by the addition of some cultural facets to the curriculum or by the provision of a programme to meet needs not met by the home culture or family. It involves a small move towards the acceptance of the rights and validity of indigenous and ethnic minority cultures, assuming that ethnic bits can be added to the curriculum without either re-contextualising them or fitting them into a culturally appropriate philosophical base.

Typically, this attributes values to a culture when it was "simpler, nobler and more honest". In other words, it is romantic, unrealistic and patronising. "Interesting" rites and customs are studied and mythological heroes are identified. Ethnic units are provided in social studies, and the cultures of other groups are acknowledged, but only in a marginalising and superficial way.

Often this sort of acknowledgment adds up to a form of "cultural commodification" - making commodities of people's cultures - be it material, mythic or cognitive. This is seen in Aotearoa/New Zealand when the All Blacks perform the haka or children are taught waiata and poi dances at school as an indication of that school's acknowledgment of Maoritanga. ${ }^{11}$ These items are presented out of context and the mana and spirituality is ripped out of them.

5. The self-concept development paradigm. This paradigm moves beyond tokenism in that it assumes that indigenous/ ethnic-minority children have low self-esteem because of the inequitable and controlling socio-economic reality that confronts them. The remedy is to increase the child's selfesteem by curriculum developments that emphasise the contributions of ethnic minorities to the national culture and show ethnic heroes as national heroes. So it introduces elements of the culture as the ethnic additive paradigm does, but it also attempts to address the psychological needs of the child. While the intentions within this paradigm may be good, it can be argued that such changes needs to come from within the culture, rather than from the outside by non-ethnic "experts". 


\section{The multicultural stage}

The multicultural stage is characterised by the beginnings of the acknowledgment of cultural diversity in a more substantial fashion. There is the start of a true recognition of different cultural styles and the language of ethnic minority/indigenous groups is seen as central to cultural survival.

Irwin (1989) defines multiculturalism in the following way:

A multicultural society... is one in which all cultural groups are able to make sense of the world, communicate with each other and plan and live their lives as they see fit. (p. 7).

The British Swann Report (1985) gives a useful description of multiculturalism:

We consider that a multicultural society such as ours would in fact function most effectively and harmoniously on the basis of pluralism which enables, expects and encourages members of all ethnic groups, both minority and majority, to participate fully in shaping the society as a whole within a framework of commonly accepted values, practices and procedures, whilst also allowing and, where necessary, assisting the ethnic minority communities in maintaining their distinct ethnic identities within the common framework (p. 15).

Cultural difference is the only paradigm that relates solely to multiculturalism, while the language and cultural pluralism paradigms possess qualities which could fit either within a multicultural or bicultural framework. This is because the relationship between multiculturalism and biculturalism is dependent on context. In the Aotearoa/New Zealand setting, biculturalism is appropriate with all its attendant paradigms because of the tangata whenua/Tauiwi relationship, while elsewhere multiculturalism or anti-racism may be the crucial and necessary approach.
6. The cultural difference paradigm. This paradigm acknowledges the importance of a group's unique world view. Here, language, values, mores, patterns of organisation and cultural characteristics are acknowledged and seen as "functional for them and valuable to the nation state" (Banks, p. 97); and their development in schools is supported in policy and practice, i.e., there is now an acceptance of diversity as an enriching rather than as a divisive characteristic. The aim of the paradigm is to change the school through the existing power structures so that it both respects and legitimises the cultures of students not part of the dominant culture.

\section{The bicultural stage: towards an educational partnership}

Biculturalism in Aotearoa/New Zealand is characterised as equal development of the two main groups, Maori and Tauiwi, in separate but parallel paths. It is about power-sharing and mutual respect. Along with the language and cultural pluralism paradigms, the anti-racist and radical paradigms fit within this stage.

7. The language paradigm. A further step in taking away blame for failure from ethnic minorities can be found in what Banks terms the language paradigm. This paradigm goes a step further than the cultural difference paradigm in not only acknowledging the importance of language but also in developing policy and programmes for its teaching and its recognition as a taonga, a treasure. The paradigm stresses the importance of the first language for the educational survival of indigenous/ethnic minority children, i.e., children do not succeed in the school system because they are not educated in their first language. The policies encourage the development of bilingual and language immersion programmes.

8. The cultural pluralism paradigm. Cultural pluralism has a similar theme to the cultural difference paradigm but is more developed. It recognises education as having an important 
role in not only acknowledging but also actively promoting ethnic identification - in Banks' words, "To promote the maintenance of groups; to promote the liberation of ethnic groups and to educate them in a way that will not alienate them from their home cultures" (p. 97). In concrete terms, this means the creation of ethnic studies courses that are philosophically and ideologically based, and ethnically-based schools that focus on "the maintenance of ethnic cultures and traditions" (p. 97), i.e., cultural pluralism supports bilingual and/or separate development.

Maori Departments at universities, Kura Kaupapa Maori schools, Kohanga Reo, Te Wananga o Raukawa and Pacific Island language nests are examples of this approach. Ethnically-based studies are means and ends in their own right rather than meaningful additives to what remains, in essence, a monocultural education system. ${ }^{12}$ This paradigm could well work in partnership with the language paradigm to develop an emancipated language/culture programme.

9. The anti-racist paradigm (Banks terms this the racism paradigm). Other than the radical paradigm, the anti-racist paradigm provides the most daring approach to multiethnic education. All previous paradigms value the indigenous/ ethnic minority culture to varying degrees, from not at all, in the assimilationist and genetic paradigms, to very valued in the cultural pluralist paradigm. However, in none of these instances is the dominant culture charged with any responsibility for an inequitable system of education, or in the larger sense, with a social system in which minority individuals cannot really succeed. In the worse case scenario of the assimilationist/genetic paradigm, the minority cultures are held responsible for their own situation, i.e., the victim is blamed. In the more liberal scenarios, those holding power are prepared to take steps in varying degrees to "give a helping hand" (in the case of the cultural difference paradigm) or fully to support the ethnic minority (in the cultural pluralism paradigm); but in none of these does the dominant group accept responsibility for the creation of the inequality.

The anti-racist paradigm shifts the blame for school failure onto the dominant society. It suggests that the reason there is educational inequality is racism, and that the school should play a major role in eliminating personal and institutional racism both in schools and in the wider society. This should be done through anti-racist workshops and courses for teachers, and anti-racist lessons for students, with an examination of curriculum materials, personnel, teaching attitudes and school norms.

10. The radical paradigm. This is, as the name suggests, the most challenging of all the paradigms. I would argue that its aims could coincide with an extreme form of biculturalism that wishes to overturn contemporary society as it stands to create a better and more equitable world. From a radical perspective, schools, as well as society's other central institutions, are seen as purporting to be neutral, but in fact representing the status quo and the interests of the dominant group. When addressing educational issues, supporters of this paradigm state that there should be no policy to institute change in education without addressing the larger issues within the whole of society.

In this scenario, the school is central to the problem and plays a key role in keeping minority groups oppressed. Thus it is not possible for the school to help liberate oppressed groups because one of its central purposes is to educate students so that they willingly accept their assigned status in society. A primary role of the school is seen as reproducing the social class structure and its consequent ethnic dimension. Exponents of the radical paradigm argue against programmes of multiethnic education because they are seen as palliative, i.e., they are designed to keep oppressed groups from rebelling against a system that promotes structural barriers through institutionalised racism and do not deal with the real issues of ethnic oppression and victimisation. 


\section{Towards the future}

An exercise such as the above should help to disentangle the various strands which need to be understood when considering issues relating to multiethnic education.

In the past, Pakeha educators and administrators have made decisions on behalf of Maori. Now it is necessary to develop a system that is based on clear appraisal of Maori and Tauiwi needs, developing what is appropriate for all of these needs but in support of and in conjunction with each other. When addressing the needs of bicultural education, at least two multi-factor paradigms are needed; the priorities of Maori and Tauiwi are different, but need to be considered in relation to each other. Biculturalism does not regard separate development as a threat, and since the needs of Maori are well catered for by Maori educators, the partnership equation is weaker on the Tauiwi side now than on the Maori. Hypothetically, a multi-factor paradigm for Maori could encompass challenging the status quo as the radical paradigm does, but also developing the underlying intentions of the cultural pluralism and language paradigms. For the Tauiwi side of the partnership, I would suggest that the main concern for Pakeha should be addressing issues in the anti-racist and radical paradigms, and for Pacific Island and other groups to make known and to develop policy and practice for their specific needs.

Having established then that we are in a phase of biculturalism and having examined the attendant paradigms, it is necessary to consider where to go from here.

Howard (1993), when discussing whites in multicultural education in the United States, asks:

How does an ethnic group that has historically been dominant in its society adjust to a more modest and balanced role? Put differently, how do white Americans learn to be positive participants in a richly pluralistic nation? ... Too many segments of our white American population remain committed to their position of dominance; they are willing to defend it and legitimize it, even in the face of overwhelming evidence that our world is rapidly changing. Taken as a whole, these realities strongly suggest that a peaceful transition to a new kind of America, in which no ethnic or cultural group is in a dominant position, will require considerable change in education and deep psychological shifts for many white Americans. Attempting to effect these changes is part of the work of multicultural education, and that challenge leads us to a central question: What must take place in the minds and hearts of white Americans to convince them that now is the time to begin their journey from dominance to diversity? (pp. 36-37).

Howard's evaluation of the need for cultural responsibility in the United States applies equally in Aotearoa/New Zealand. Amidst the diversity of the Tauiwi, it may be argued that the responsibility for the efficacy of biculturalism rests with them as a whole. Maori have created, both within and outside of the existing structures, their own solutions to inequity and marginalisation. They have upheld biculturalism and all its attendant implications, and now the Tauiwi must build their side of the partnership and address the historical and philosophical context of Aotearoa/New Zealand as it stands poised for the twenty-first century.

\section{Notes}

1. The term "multiethnic" has been chosen to describe the various forms of education that address biculturalism and multiculturalism. Banks (1988, pp. 33-37) discusses the goals of multiethnic education and defines it in the following way:

Multiethnic education is a reform movement designed to make some major changes in the education of children and youths. Advocates of multiethnic education believe that many school practices related to race and ethnicity are harmful to students and reinforce many ethnic stereotypes and discriminatory practices in Western societies. (p. 33) 
2. For an excellent overview of this development, particularly in relation to the Kohanga Reo movement, see Irwin (1992).

3. Kawharu (1989) describes three major Waitangi Tribunal claims: Mana and the Crown: a Marae at Otaki (written by Kawharu himself); the Muriwhenua Claim (Waerata Norman); and Tipene O'Regan's The Ngai Tahu Claim. These provide a useful description of the conflict between Maori and Pakeha readings of the Treaty and clearly illustrate the Maori perspective.

4. She states in her 1989 paper that they are used interchangeably.

5. Having said this, however, it is also true that we have not moved cleanly from one phase to another, either overnight or completely; for example, although I would argue that we are now in a bicultural stage, this does not mean that we all share ideologies or support policies that are bicultural. Rather, there is a mixture of people who support ideologies from the assimilationist, integrationist and multicultural stages, and these ideologies and their policies and practices are in competition with one another even though they present policy emphasis is bicultural.

6. McNair (1961) states that in relation to the interpretation and application of treaties the principle of contra preferentum applies:

The decisions contain frequent references to a rule that, in the case of ambiguity, a provision must be construed against the party which drafted or proposed the provision, which appears to mean that in any case of doubt the other party should have the benefit of the doubt. (p. 464)

In the case of the Treaty of Waitangi this means that Maori interpretations, particularly of kawanatanga and tino rangatiratanga must have precedence over Pakeha interpretations. This stance is further strengthened in relation to another principle he mentions, that of good faith. He states that:

The performance of treaties is subject to an over-riding obligation of mutual good faith. This obligation is also operative in the sphere of interpretation of treaties, and it would be a breach of this obligation for a party to make use of this ambiguity in order to put forward an interpretation which was known to the negotiators of the treaty to be contrary to the intentions of the parties. (p. 465)
While it could be argued that in such a case there were two understandings of the Treaty rather than a manipulation of an ambiguity, the principle of contra preferentum would still uphold the case for a Maori interpretation of the Treaty.

7. Banks acknowledges Kuhn (1970) and Barnes (1982) for the development and explanation of the paradigm.

8. See Jensen (1969), Schockley (1972) and Herenstein (1971). This conflict led to a larger debate where those opposing the genetic argument argued that IQ tests were in fact biased towards the knowledge-base of the white middle class. In New Zealand a similar storm blew up over the use of TOSCA, the test of scholastic ability designed by NZCER as a tool to determine which stream students would go into when they entered secondary school. It was claimed that TOSCA was in fact an intelligence test and that it was culturally biased against Maori students. For more information on the TOSCA debate, see the articles and letters (particularly the ongoing jousting between Nash and Reid) in NZJES (see References: TOSCA articles). (Timoti Karetu, formerly professor of Maori at Waikato University and presently the Maori Language Commissioner, designed the MOTIS test, a Maoricontext IQ test parodying the American OTIS test).

9. The self-fulfilling prophecy works in the following way: those who are placed in higher streams are expected to learn more and do better, they are given more support, have good self-esteem and do well, as expected. Those assigned to lower streams, however, are given the message that it is suggested that they will learn less and perform poorly, and consequently they receive less support, have lower self-esteem and, as predicted, they do poorly. See Rist (1970).

10. See Harker (1990) pp. 34-37 for a useful explanation of this process.

11. It is not the teaching of these items per se, as much as the fact that, when taught by Pakeha, they are often taken out of context, trivialised and made tokenistic.

12. Although Banks does not identify the indigenous or first language as central to or even as part of the cultural pluralism paradigm, it 
is hard to envisage this or the less radical cultural difference paradigm without a strong linguistic component.

\section{References}

Banks, J. A. Multiethnic Education: Theory and Practice (2nd edition), Boston: Allyn and Bacon Inc., 1988.

Barnes, B. T. S. Khun and Social Science, New York: Columbia University Press, 1982.

Barrington, J. M. “Cultural Adaptation and Maori Educational Policy: The African Connection", in Comparative Education Review, February, Vol. 19, No. 2, 1976, pp. 1-10.

Barrington, J. M. "From Assimilation to Cultural Pluralism: A Comparative Analysis", in Comparative Education, March, Vol. 17, No. 1, 1981, pp. 59-69.

Barrington, J. M. "Learning the 'Dignity of Labour': secondary education policy for Maoris", in New Zealand Journal of Educational Studies, Vol. 23, No. 1, 1988, pp. 45-58

Brandt, G. L. The Realisation of Anti-Racist Teaching, Lewes: The Falmer Press, 1986.

Department of Education and Science Education for All (The Swann Report) Cmnd 9453, London: HMSO.

Department of Statistics Maori Population Projections 1991 (Base) - 2031 Christchurch: Department of Statistics, 1993.

Harker, R. "Schooling and Cultural Reproduction". In J. Codd, B. Harker and R. Nash (eds) Political Issues in New Zealand Education (2nd edition), Palmerston North: The Dunmore Press, 1990.

Herrenstein, R. J. “I. Q." Atlantic Monthly, September, Vol. 43, 1971, p. 64.

Howard, G. R. "Whites in Multicultural Education: Rethinking our Role", in Phi Delta Kappan, September, 1993, pp. 36-41.

Hunn, J. K. Report on the Department of Maori Affairs, Wellington: Government Printer, 1960.
Irwin, K. "Multicultural Education: The New Zealand Response", in New Zealand Journal of Educational Studies, Vol. 24, No. 1, 1989, pp. 3-18.

Irwin, K. "The Politics of Kohanga Reo". In S. Middleton, J. Codd and A. Jones (eds) New Zealand Education Policy Today: Critical Perspectives, Wellington: Allen and Unwin New Zealand, 1990.

Jensen, A. "How Much Can We Boost IQ and Scholastic Achievement?", in Harvard Educational Review, Winter, Vol. 39, 1969.

Kawharu, I. A. (ed) Maori and Pakeha Perspectives in the Treaty of Waitangi, Oxford: Oxford University Press, 1989.

Khun, T. S. The Structure of Scientific Revolution (2nd edition), Chicago: University of Chicago Press, 1970.

McNair, Lord The Law of Treaties, Oxford: Oxford University Press, 1961.

Ministry of Education/Te Tahu o te Matauranga Ten Point Plan for Maori Education: 1992 Action Plan, Wellington: Ministry of Education, 1992.

Ministry of Education Corporate Plan 1993/94, Wellington: Learning Media, 1993.

Parata, H. "Mainstreaming - A Maori Affairs Policy?", in Institute of Policy Studies Newsletter, November, No. 36, 1993, pp. 19-20.

Pearson, D. A Dream Deferred: The Origins of Ethnic Conflict in New Zealand, Wellington: Allen and Unwin New Zealand, 1991.

Peters, M. and Marshall J. “Te Reo o Te Tai Tokerau: Language Evaluation and Empowerment", in New Zealand Journal of Educational Studies, Vol. 24, No. 2, 1989, pp. 141-157.

Rist, R. "Students' Social Class and Teachers' Expectations: The Selffulfilling Prophecy in Ghetto Education", in Harvard Educational Review, August, Vol. 40, 1970, pp. 411-451.

Rocher, G. "The Ambiguities of a Bilingual and Multicultural Canada". In J. R. Mallea and J. C. Young (eds) Cultural Diversity and Education: Issues and Innovations, Ottawa: Carleton University Press, 1984. 
Schockley, W. "Dysgenics, Genetics and Raceology: Challenges to the Intellectual Responsibility of Educators", in Phi Delta Kappan, January, 1972, pp. 297-307.

Simon, J. "Aspirations and Ideology: Biculturalism and Multiculturalism in New Zealand Education", in Sites, Winter, No. 18, 1989, pp. 23-34.

Smith, G. H. "Taha Maori: Pakeha Capture”, in J. Codd, R. Harker and R. Nash (eds) Political Issues in New Zealand Education, Palmerston North: The Dunmore Press, 1990.

Spoonley, P., Macpherson, C., Pearson, D. and Sedgwick, C. Tauiwi: Racism and Ethnicity in New Zealand, Palmerston North: The Dunmore Press, 1984.

Spoonley, P., Pearson, D. and Macpherson, C. Nga Take: Ethnic Relations and Racism in Aotearoa/New Zealand, Palmerston North: The Dunmore Press, 1991.

Street-Porter, R. Race, Children and Cities, Milton Keynes: Open University Press, 1978.

Vasil, R. Biculturalism: Reconciling Aotearoa with New Zealand, Wellington: Institute of Policy Studies, 1988.

\section{TOSCA ARTICLES}

Ballard, K. D. "Psychometrics Versus the Individual Child: A Response to Reid and Croft", in New Zealand Journal of Educational Studies, Vol. 20, No. 1, 1985, pp. 93-94.

Ballard, K. D. "The Need to Focus on the Individual Child: A Comment on TOSCA", in New Zealand Journal of Educational Studies, Vol. 19, No. 2, 1984, pp. 157-159.

Beck, L. R. and St. George, R. "The Alleged Cultural Bias of PAT: Reading Comprehension and Reading Vocabulary Tests", in New Zealand Journal of Educational Studies, Vol. 18, No. 1, 1983, pp. 32-47.

Matthews, D. A. “The Use of Standardised Tests: A Practitioner's Point of View", in New Zealand Journal of Educational Studies, Vol. 18, No. 2, 1983, pp. 171-178.
Nash, R. "Four Charges against TOSCA", in New Zealand Journal of Educational Studies, Vol. 18, No. 2, 1983, pp. 154-165.

Nash, R. "Ability, Attainment, Prediction and Bias", in New Zealand Journal of Educational Studies, Vol. 19, No. 2, 1984, pp. 152-156.

Reid, N. and Croft, C. "Replies to Nash and Ballard", in New Zealand Journal of Educational Studies, Vol. 19, No. 2, 1984, pp. 162-169.

Reid, N. and Croft, C. "Response to Ballard: Final Comment", in New Zealand Journal of Educational Studies, Vol. 20, No. 2, 1985, pp. 192-193.

Reid, N. and Gilmore, A. "Pupil Performance on TOSCA: Some Additional Information", in New Zealand Journal of Educational Studies, Vol. 18, No. 1, 1983, pp. 13-31.

Reid, N., Gilmore, A. and Croft, C. "In Defence of TOSCA: Reply to Nash's 'Four Charges ...' ", in New Zealand Journal of Educational Studies, Vol. 19, No. 1, 1984, pp. 15-23.

St. George, R. and Chapman, J. W. "TOSCA Results from a New Zealand Form I Sample", in New Zealand Journal of Educational Studies, Vol. 18, No. 2,1983, pp. 178-183.

St. George, R. and Chapman, J. W. "Maori and European Ability Group Placements: TOSCA versus PATs", in New Zealand Journal of Educational Studies, Vol. 19, No. 2, 1984, pp. 160-161.

Tuck, B. F. "Education and Test of Scholastic Ability: Is There a Baby in the Bathwater?", in New Zealand Journal of Educational Studies, Vol. 18, No. 2, 1983, pp. 165-171.

\section{The author}

Keith Sullivan is a Lecturer in Education at Victoria University of Wellington. He teaches courses in classroom studies, education, multiethnic education and New Zealand education. 